\title{
Exploring the Nexus Between Research and Development Expenditures and Corporate Financial Performance: A Sectoral Analysis
}

\author{
Geoffrey VanderPal \\ Purdue University Global
}

The financial outcomes of research and development ( $R \& D)$ expenditures are not instantaneous and straightforward. To explore the varied perspectives of these relationships this study employs Generalized Method of Moments (GMM). Analyses reveals significant variances in different asset classes and in different sectors, besides finding the evidence of multiple regimes. The findings provide insights in the risk-return paradigm of $R \& D$ investment, and the successive return, besides helping the policy makers to settle the priority sector to get the expected result in line with the country's investment policy.

Keywords: R\&D, Research and Development, Financial Performance, Corporate Finance

\section{INTRODUCTION}

Research and Development (R\&D) is indispensable for survival in this progressively competitive business environment. To thrive in this competitive environment, there is a bigger demand for $\mathrm{R} \& \mathrm{D}$. The firms which allocate higher R\&D expenditures are expected to earn more than those that do not (ChaoHung Wang, 2011). Corporate R\&D expenditures are largely focused on creating knowledge assets, partly implanted in human capital, and customarily very specialized to the particular industry in which it exists(Hall \& Lerner, 2010). Hence, in order to gain competitive advantage, firms undertake costly R\&D activities to develop innovations (Thatcher \& Pingry, 2009). Successful R\&D activities aids in increasing firms value and bear significance for corporate managers. So, the relationship between R\&D expenses and financial performance is vital for firm's managers whose aim is to maximize the present values of stocks (Tubbs, 2007).

Recognizing the significance, in recent years, there has been an increasing interest in academics from different field of studies to understand the relationship dynamics between R\&D expenditures and financial performance. However, previously published studies on the effect of R\&D expenses is not consistent. What is less clear is the nature of the relationship for diverse sectors - whether and how such relationship dynamics varies. This paper attempts to show the sectoral differences of R\&D expensefinancial performance nexus. Besides, the Generalized Method of Moments (GMM) are employed to catch on the lag effect bearing in mind that the R\&D expense outcome is not immediate.

This study aims to contribute to this growing area of research by exploring the relationship from diverse viewpoints. Primarily, the study wants to investigate the relationship between R\&D expenditures made by the firms and their financial performance. Besides looking into the R\&D expense, it considers the ratio of such expense to operating income, to have an understanding in a relative manner. 
The following section presents the literature review on R\&D expenses and present the gap in the existing literature. then follows a description of the data, methodology and the econometric aspects of the study and present the empirical models to achieve the study objective. Then follows a presentation of the main findings and discussion, before concluding with the implications of the findings.

\section{LITERATURE REVIEW}

The current study reflects a knowledge-based perspective of firms which consider organisations as repositories of knowledge (Grant, 1996; Kogut \& Zander, 1992). The research on the impact of R\&D investments on business performance has therefore ignited great interest from academia. Likewise, there is increasing interest from businesses to understand the relationship nexus to enable them to make more strategic and impactful investment decisions. There are numerous theoretical perspectives that describe the relationship, which include the dynamic resource-based view (Helfat and Peteraf, 2003), and this has been confirmed by a number of empirical studies (e.g. Eberhart, Maxwell \& Siddique, 2004; Lome, Heggeseth \& Moen, 2016). To date, various studies have explored the role of investing in R\&D from diverse viewpoints.

Lome, Heggeseth and Moen (2016) examined the effects of high R\&D intensity on performance during a financial crisis. From a survey distributed to senior managers of 2415 Norwegian SME manufacturing exporters, they found that firms who devoted considerable resources to R\&D activities performed significantly better than other firms during the financial crisis of the late 2000s. However, their study does not provide comprehensive understanding of the firms' performance during a crisis period, as the study was based on a single country setting and did not consider any macroeconomic influences on performance. Teirlinck (2017) provides the understanding of the strategic decisions made in R\&D during the financially turbulent period of 2009 to the financial health of firms in the period of $2010-2013$ and claims that firms benefit from more engagement in research-oriented activities, more in-house innovation, and enhancement of absorptive capacity in sets of strategic R\&D decisions. Higher engagement and expenditure in $R \& D$ generate larger brand value which in turn could be translated into larger firm-level financial performance metrics (Peterson \& Jeong, 2010).

Firms' expenditure are however often not straightforward, but rather a contingent decision. Firms are less willing to reduce their R\&D levels following a negative growth shock than they are willing to increase R\&D after a positive shock (Coad and Rao, 2009). They provide a comprehensive analysis by considering US manufacturing firms from 1973 - 2004 with focus on the co-evolution of sales growth, employment growth, profits growth and the growth of R\&D expenditure. They also confirm that sales growth has a more persistent influence on the $R \& D$ growth. However, firms are not very keen to reduce their R\&D expenditure levels following a negative growth shock as much as they are willing to increase $\mathrm{R} \& \mathrm{D}$ after a positive shock; based on the performance feedback of firms that adjust their level of investment in R\&D continuously (Jirásek, 2017). In addition, the level of R\&D expenditure and financial performance relationship varies according to the nature of business, with the link being more powerful for more productive and innovative organisations (Pandit, Wasley, \& Zach, 2009).

These elements allow businesses to enjoy competitive advantages in terms of market power. Being a lead firm in innovation through R\&D investment is strongly related to higher financial performance that could improve firms' potential future earnings (Shin et al., 2008). Firms count on their opportunities to exploit innovative products and services, thus forcing them to strongly invest in R\&D. The expenditures signal the strategic positioning of a firm and significantly put a strain on the firm's financial performances (Lantza \& Sahutb, 2005; Rivette \& Klein, 2008). Duqui, Mirti, \& Torluccio (2011) confirmed such claims by assessing the impact of R\&D on stock returns for a group of European countries, where they found a positive significant effect of R\&D investments in appraising future returns.

Relatively, firms which invest in R\&D are found to have formed a positive correlation between R\&D intensity and the company's performance; and impact of R\&D investments is two times higher on market capitalisation as compared with investments in tangible assets (Hsieh et al., 2003). On average, a firm that engages in R\&D activities earns $4 \%$ to $11 \%$ higher sales and generates $4 \%$ to $13 \%$ more profits than firms 
that do not engage in R\&D activities (Rafiq, Salim, \&Smyth, 2016). Yet, the consequences are not instantaneous and mostly dependent on the time lag between the moment the R\&D spending was incurred and the point at which it improved financial sustainability, which varies from business to business (Dave, Wadhwa, Aggarwal, \& Seetharman, 2013). Martin (2015) established a strong variant in terms of the efficiency of various categories of inventive expenditure, by evaluating the effectiveness of various types of business innovation expenditures of manufacturing enterprises. He found relatively strong and consistently positive lagged random effects (RE) of both internal and external R\&D expenditure.

Past studies have discussed the impacts of $R \& D$ expenditure and consequential performance of firms, particularly their financial performance. The effect of such expenditure was found heterogeneous for growing or shrinking firms (Coad \& Rao, 2009). Such mix outcomes may occur due to the variations among R\&D related dependent measures (Jirásek, 2018). Nonetheless, most researchers conclude that investment in R\&D has positive impact on profitability (Lin, Yang \& Liou, 2008; Martin, 2015; Jirásek, 2017). In certain cases however, some authors have failed to find a significant relationship between firms' R\&D spending and performance (Shin, Kraemer \& Dedrick, 2008). There are also research findings that highlight how the decision to capitalise $R \& D$ is often associated with a negative or neutral impact on future performance (Cazavan-Jeny, Jeanjean and Joos, 2011). The inconclusiveness in the current literature points to the need for further investigation to ascertain the relationship between $R \& D$ investments and firm's corporate financial performance.

\section{METHODOLOGY AND ANALYSIS}

Different methodologies were employed to accomplish the study objectives where the key interest is to find out the how firms' financial performances are affected by investing in R\&D. Similarly, sectoral segregation is made to comprehend the sector-wise idiosyncrasy. For this study, we collected the data from Compustat S\&P 500 companies. Data frequency is annual, and it covers a range from 1979-2015. The table below summarizes the methodological aspects for the current study.

TABLE 1

METHODOLOGY WE USED

\begin{tabular}{|r|l|l|l|l|}
\hline No & Issues & \multicolumn{2}{|l|}{ Proxies/Variables } & Description \\
\hline 1. & $\begin{array}{l}\text { Effect of R\&D } \\
\text { expenses on } \\
\text { Financial } \\
\text { Performance }\end{array}$ & Independent & Dependent & $\begin{array}{l}\text { Difference GMM and System GMM are } \\
\text { employed to see the effects of R\&D } \\
\text { expenditures as well as the lag effects } \\
\text { on financial performances. }\end{array}$ \\
\cline { 5 - 5 } & RDE & ROA, ROE/OPI & RDE \\
\cline { 3 - 5 } & $\begin{array}{l}\text { Sectoral variations of } \\
\text { R\&D expenditures- } \\
\text { financial } \\
\text { performance } \\
\text { relationship }\end{array}$ & RDE & ROA, ROE & $\begin{array}{l}\text { Difference GMM and System GMM are } \\
\text { employed separately for 10 sectors to } \\
\text { catch on how sectoral spending } \\
\text { dissimilarities on R\&D activities result } \\
\text { in their financial performance } \\
\text { variations. }\end{array}$ \\
\cline { 2 - 4 }
\end{tabular}

In statistics, ordinary least squares (OLS) is a method for estimating the unknown parameters in a linear regression model. The OLS is considered a classical estimation method as the OLS estimator provides minimum-variance mean-unbiased estimation when the errors are homoscedastic and serially uncorrelated. However, one important issue is that most models have concerns with the endogeneity problem, which occurs when an explanatory variable correlates with the error term due to omitted variables, measurement errors, or simultaneity (Wooldridge, 2006). For the current study, R\&D expenditure is endogenous and is correlated with the error term and the classical OLS regression model might produce inefficient regression coefficient. To overcome these possible problems, the study uses the 
generalized method of moments (GMM) estimators developed for dynamic panel data that was first introduced by Hansen (1982) and proposed by Holtz-Eakin et al. (1988) and Arellano \& Bond (1991). The GMM estimator has several advantages in particular for this study. Firstly, the GMM is an appropriate method for the research data structure and it performs well for the unbalanced dataset. Secondly, it can reduce the endogeneity problem due to the potential correlation between regressors and the error term. Thirdly, this research use lagged dependent variables, thus, the dynamic GMM panel is the most appropriate method to address this type of data structure. Fourth, dynamic GMM panel data estimation is more appropriate in cases where some unobservable factors affect both the dependent variable and the explanatory variables and some explanatory variables are strongly related to past values of the dependent variable. Furthermore, introducing lagged values of the dependant variable in OLS estimators may seriously bias estimated coefficients (Nickell, 1981). In consideration of the above, heteroskedasticity and the properties of our panel dataset, Arellano and Bond's two-step difference GMM estimator is used. This dynamic Generalised Methods of Moments (GMM) estimator ensures a consistent and reliable estimation of the parameters of interest (Roodman, 2006). In general, the consistency of GMM estimator depends on the validity of the assumption that the error terms do not exhibit serial correlation and on the validity (exogeneity) of its instruments. To validate these assumptions, STATA ${ }^{1}$ offers two sets of specification tests. The first set constitutes $\operatorname{Sargan}^{2}$ and Hansen test $^{3}$ of over-identification.

To check for first-order serial correlation in levels, we look for second-order correlation in differences AR (2) (Mileva, Bruhn, \& Weickert, 2007). Autocorrelation in levels indicates that lags of the dependent variable (and any other variables used as instruments) are not strictly exogenous but in fact endogenous, thus bad instruments. Failure to reject the null hypotheses of the over-identification and serial correlation tests gives support to our model.

To eliminate the potential bias caused by omitted heterogeneity, we can either use fixed effects or random effects models. If the independent variables are uncorrelated with the unobserved effect $(\mu \mathrm{i})$, the fixed effects estimator is consistent but inefficient, whereas the random effects estimator is consistent and efficient. If the independent variables are correlated with the unobserved heterogeneity ( $\mu \mathrm{i})$, the fixed effects estimator is consistent, while the random effects estimator is inconsistent (Baum, 2006). So, to identify the appropriate estimation model, we run Hausman test. If the null hypothesis is rejected, then we conclude that $\mu \mathrm{i}$ is correlated with the independent variables, i.e. the fixed effects is the appropriate method (Pasiouras \& Kosmidou, 2007; Petria, Capraru, \& Ihnatov, 2015). Moreover, assuming homoscedasticity of error terms in the presence of heteroscedasticity, as well as having autocorrelated disturbances, produces consistent but inefficient estimates, and the standard errors of these estimates will be biased (Baltagi, 2005). Therefore, we shall estimate robust standard errors to correct for the possible presence of these issues.

TABLE 2

\section{LIST OF VARIABLES}

\begin{tabular}{|c|c|}
\hline Variable Name & Symbol \\
\hline Assets-Total & AST \\
\hline EBIT & EBI \\
\hline Net Income (Loss) & NEI \\
\hline Op Income Bef Depreciation & OPI \\
\hline Price-Close Calendar Year & PRI \\
\hline R\&D Expense & RDE \\
\hline ROA & ROA \\
\hline ROE & ROE \\
\hline Sales-Net & SAL \\
\hline R\&D Expense ratio & RDE/OPI \\
\hline
\end{tabular}


Following to the methodology explained, we report and analyse the various estimations (i.e. GMM). In general, the results of the most estimations indicates the significance of the lag dependent variable (i.e.), in line with earlier findings in other empirical studies that what confirm the appropriateness of using the GMM technique.

\section{Descriptive Statistics}

Table 3 summarizes the median values of our main variables of corporate firms. It presents the summary statistics for the aggregated data. Clearly, the data are characterised by their heterogeneity, where the differences among corporate firms are significant.

TABLE 3

DESCRIPTIVE STATISTICS

\begin{tabular}{lccccc}
\hline Variable & No. of Observations & \multicolumn{1}{l}{ Mean } & Standard Deviation & Minimum & Maximum \\
\hline ROA & 14314 & 5.259422 & 11.52165 & -577.85 & 90.66 \\
ROE & 14008 & 15.35914 & 159.9642 & -14132 & 7038.46 \\
RDE & 7500 & 472.8612 & 1205.228 & 0 & 12540 \\
LAST & 14322 & 8.569283 & 1.930882 & -1.17766 & 14.76063 \\
LNEI & 13037 & 5.611215 & 1.773562 & -6.90776 & 11.56001 \\
LEBI & 13714 & 6.209501 & 1.721655 & -3.07911 & 11.17367 \\
NEI & 14314 & 836.5912 & 2946.255 & -99289 & 104821 \\
OPI & 13723 & 2238.955 & 5350.579 & -76735 & 81730 \\
PRI & 13913 & 32.88359 & 59.03339 & 0.01 & 1971.25 \\
\hline
\end{tabular}

\section{Correlation Coefficient}

Table 4 provides the matrix of Pearson correlation coefficients that, based on the results, indicate relatively weak association between the variables.

TABLE 4

CORRELATION COEFFICIENT

\begin{tabular}{lrrrrrrrrr}
\hline Variable & \multicolumn{1}{l}{ ROA } & ROE & RDE & LAST & LNEI & LEBI & NEI & OPI & PRI \\
\hline ROA & 1 & & & & & & & & \\
ROE & 0.1457 & 1 & & & & & & & \\
RDE & 0.0574 & -0.011 & 1 & & & & & & \\
LAST & -0.1836 & 0.0041 & 0.5609 & 1 & & & & & \\
LNEI & 0.2576 & 0.0504 & 0.5415 & 0.8619 & 1 & & & & \\
LEBI & 0.1405 & 0.0516 & 0.5438 & 0.9109 & 0.9449 & 1 & & & \\
NEI & 0.1852 & 0.0309 & 0.6152 & 0.6526 & 0.7036 & 0.6845 & 1 & & \\
OPI & 0.052 & 0.0173 & 0.6072 & 0.7103 & 0.681 & 0.7075 & 0.9282 & 1 & \\
PRI & 0.1306 & 0.0221 & 0.1703 & 0.1722 & 0.2282 & 0.222 & 0.1507 & 0.1146 & 1 \\
\hline
\end{tabular}

\section{Model with Different Set of Control Variables}

The following table (Table 5) reports the estimation results of the various estimations to find the appropriate technique. Lag depended variable is found significant,referring to the dynamic nature of the dependent variable. Because of that we tend to choose dynamic panel technique (GMM), instead of static 
panel technique (fixed effect or random effect) or OLS. For all the proxies of dependent and focus variables, OLS, static and dynamic panel techniques have been computed and results are referred in appendix. The mentioned Table also demonstrates the results of the various estimations with different set of control variables using the same methodology used in estimating the basic models. All estimations pass the Sargan test, thus validate the robustness of the study results.

TABLE 5

DIFFERENT PANEL MODELS OF REGRESSION

\begin{tabular}{|c|c|c|c|c|c|}
\hline & OLS & Fixed Effect & $\begin{array}{l}\text { Random } \\
\text { Effect }\end{array}$ & $\begin{array}{l}\text { Difference } \\
\text { GMM }\end{array}$ & System GMM \\
\hline RDE & $\begin{array}{c}0.000205^{* * * *} \\
(6.01)\end{array}$ & $\begin{array}{c}-0.000404^{* * *} \\
(-9.02)\end{array}$ & $\begin{array}{c}-0.000282^{* * *} \\
(-6.65)\end{array}$ & $\begin{array}{c}-0.000712^{* * *} \\
(-6.47)\end{array}$ & $\begin{array}{c}-0.000680^{* * *} \\
(-6.52)\end{array}$ \\
\hline LAST & $\begin{array}{l}-6.876^{* * *} \\
(-115.17)\end{array}$ & $\begin{array}{l}-6.238^{* * *} \\
(-91.02)\end{array}$ & $\begin{array}{l}-6.374^{* * *} \\
(-96.68)\end{array}$ & $\begin{array}{l}-5.808^{* * *} \\
(-57.57)\end{array}$ & $\begin{array}{l}-5.744^{* * *} \\
(-59.30)\end{array}$ \\
\hline LNEI & $\begin{array}{l}3.577^{* * *} \\
(52.39)\end{array}$ & $\begin{array}{l}2.879^{* * *} \\
(45.30)\end{array}$ & $\begin{array}{l}2.997^{* * *} \\
(47.39)\end{array}$ & $\begin{array}{l}2.548^{* * *} \\
(36.29)\end{array}$ & $\begin{array}{l}2.674^{* * *} \\
(38.84)\end{array}$ \\
\hline LEBI & $\begin{array}{l}3.048^{* * *} \\
(34.45)\end{array}$ & $\begin{array}{l}3.199^{* * *} \\
(35.16)\end{array}$ & $\begin{array}{l}3.208^{* * *} \\
(36.14)\end{array}$ & $\begin{array}{l}2.747^{* * *} \\
(23.96)\end{array}$ & $\begin{array}{l}2.637^{* * *} \\
(23.94)\end{array}$ \\
\hline NEI & $\begin{array}{c}0.000253^{* * *} \\
(7.80)\end{array}$ & $\begin{array}{c}0.000339^{* * *} \\
(9.94)\end{array}$ & $\begin{array}{c}0.000324^{* * *} \\
(9.76)\end{array}$ & $\begin{array}{c}0.000534^{* * *} \\
(12.41)\end{array}$ & $\begin{array}{c}0.000537^{* * *} \\
(12.56)\end{array}$ \\
\hline OPI & $\begin{array}{c}-0.0000569^{* *} \\
(-2.84)\end{array}$ & $\begin{array}{c}-0.000113^{\text {*** }} \\
(-4.77)\end{array}$ & $\begin{array}{c}-0.000102^{* * *} \\
(-4.53)\end{array}$ & $\begin{array}{c}-0.000184^{* * *} \\
(-4.63)\end{array}$ & $\begin{array}{c}-0.000146^{* * *} \\
(-3.73)\end{array}$ \\
\hline PRI & $\begin{array}{c}0.00323^{* * *} \\
(4.19)\end{array}$ & $\begin{array}{c}0.00660^{* * *} \\
(6.92)\end{array}$ & $\begin{array}{c}0.00607^{* * *} \\
(6.90)\end{array}$ & $\begin{array}{c}0.00234 \\
(1.59)\end{array}$ & $\begin{array}{c}0.00247 \\
(1.77)\end{array}$ \\
\hline SAL & $\begin{array}{c}-0.00000554^{* *} \\
(-3.13)\end{array}$ & $\begin{array}{c}-0.00000174 \\
(-0.76)\end{array}$ & $\begin{array}{c}-0.00000295 \\
(-1.36)\end{array}$ & $\begin{array}{c}4.92 \mathrm{e}-08 \\
(0.01)\end{array}$ & $\begin{array}{c}-0.0000167^{* *} \\
(-2.65)\end{array}$ \\
\hline L.ROA & & & & $\begin{array}{c}0.0392^{* * * *} \\
(6.36)\end{array}$ & $\begin{array}{c}0.0530^{* * *} \\
(10.78)\end{array}$ \\
\hline Constant & $\begin{array}{l}26.27^{* * *} \\
(121.48)\end{array}$ & $\begin{array}{l}24.15^{* * *} \\
(94.00)\end{array}$ & $\begin{array}{l}24.60^{* * *} \\
(95.46)\end{array}$ & $\begin{array}{l}25.22^{* * *} \\
(48.66)\end{array}$ & $\begin{array}{l}24.66^{* * *} \\
(51.93)\end{array}$ \\
\hline$R^{2}$ & 0.749 & 0.674 & & & \\
\hline$A I C$ & 29417.7 & 26976.9 & . & . & · \\
\hline$B I C$ & 29478.4 & 27037.6 & . & $\cdot$ & $\cdot$ \\
\hline $\mathrm{F}$ & 2333.7 & 1539.5 & & & \\
\hline Observations & 6254 & 6254 & 6254 & 5530 & 6125 \\
\hline
\end{tabular}

Given that the GMM standard errors are downward biased, robust standard errors are recommended. A robust version of the Sargan test however is available in STATA after specifying vce(robust). Given the limitations associated with the relatively short time span covered in our panel data set, we do not include any time trend component. Tests of joint significance are conducted but not reported. In line with the arbitrary rule of thumb suggested by Roodman (2009), the number of instruments doesn't the individual units (number of groups) in the panel suggesting potential problems of instrument proliferation are not apparent. 


\section{BASELINE MODEL: FINANCIAL PERFORMANCE AND R\&D EXPENSES}

\begin{tabular}{|c|c|c|c|c|}
\hline & $\mathrm{ROA}$ & ROE & ROA & ROE \\
\hline & RDE & RDE & RDE/OPI & RDE/OPI \\
\hline L.ROA & $\begin{array}{c}0.0530^{* * *} \\
(10.78)\end{array}$ & & $\begin{array}{c}0.00337 \\
(0.94)\end{array}$ & \\
\hline L.ROE & & $\begin{array}{c}-0.0330^{* * *} \\
(-3.30)\end{array}$ & & $\begin{array}{c}-0.0283^{* * *} \\
(-4.02)\end{array}$ \\
\hline RDE & $\begin{array}{c}- \\
0.000680^{* * *} \\
(-6.52)\end{array}$ & $\begin{array}{c}-0.0253^{* * *} \\
(-3.93)\end{array}$ & & \\
\hline RDEOPI & & & $\begin{array}{c}-0.997^{* * *} \\
(-5.03)\end{array}$ & $\begin{array}{l}-7.908 \\
(-0.88)\end{array}$ \\
\hline LAST & $\begin{array}{l}-5.744^{* * *} \\
(-59.30)\end{array}$ & $\begin{array}{l}0.704 \\
(0.12)\end{array}$ & $\begin{array}{l}-5.373^{* * *} \\
(-75.98)\end{array}$ & $\begin{array}{c}-10.70^{* * *} \\
(-3.40)\end{array}$ \\
\hline LNEI & $\begin{array}{l}2.674^{* * * *} \\
(38.84)\end{array}$ & $\begin{array}{l}7.685 \\
(1.83)\end{array}$ & $\begin{array}{l}2.333^{* * *} \\
(46.43)\end{array}$ & $\begin{array}{l}5.537^{*} \\
(2.51)\end{array}$ \\
\hline LEBI & $\begin{array}{l}2.637^{* * * *} \\
(23.94)\end{array}$ & $\begin{array}{l}0.809 \\
(0.12)\end{array}$ & $\begin{array}{l}2.286^{* * *} \\
(26.41)\end{array}$ & $\begin{array}{l}6.475 \\
(1.71)\end{array}$ \\
\hline NEI & $\begin{array}{c}0.000537^{* * *} \\
(12.56)\end{array}$ & $\begin{array}{c}0.000381 \\
(0.14)\end{array}$ & $\begin{array}{c}0.000868^{* * *} \\
(29.41)\end{array}$ & $\begin{array}{c}0.00241 \\
(1.71)\end{array}$ \\
\hline OPI & $\begin{array}{c}0.000146^{* * *} \\
(-3.73)\end{array}$ & 0.000343 & $\begin{array}{c}- \\
0.000408^{* * *} \\
(-17.88)\end{array}$ & -0.00152 \\
\hline PRI & $\begin{array}{c}0.00247 \\
(1.77)\end{array}$ & $\begin{array}{l}0.105 \\
(1.14)\end{array}$ & $\begin{array}{c}0.00121 \\
(1.36)\end{array}$ & $\begin{array}{c}-0.0376 \\
(-0.88)\end{array}$ \\
\hline SAL & $0.0000167^{* *}$ & $0.000878^{*}$ & $0.0000172^{* *}$ & $0.000639^{* *}$ \\
\hline Constant & $\begin{array}{l}(-2.65) \\
24.66^{* * *} \\
(51.93)\end{array}$ & $\begin{array}{l}(2.33) \\
-38.12 \\
(-1.24) \\
\end{array}$ & $\begin{array}{c}(3.28) \\
25.80^{* * *} \\
(72.65)\end{array}$ & $\begin{array}{l}(2.86) \\
35.49^{*} \\
(2.20)\end{array}$ \\
\hline Observation & 6125 & 6001 & 11873 & 11660 \\
\hline
\end{tabular}

Given that the GMM standard errors are downward biased, robust standard errors are recommended. A robust version of the Sargan test however is available in STATA after specifying vce(robust). Given the limitations associated with the relatively short time span covered in our panel data set, we do not include any time trend component. Tests of joint significance are conducted but not reported. In line with the arbitrary rule of thumb suggested by Roodman (2009), the number of instruments doesn't the individual units (number of groups) in the panel suggesting potential problems of instrument proliferation are not apparent

RDE is found statistically significant at $1 \%$ significance level for both proxies of financial performance ROA and ROE. R\&D expenses ratio is found to be significant for ROA but insignificant for ROE. These results support the assumption that R\&D expense has significantly affected the firm's financial performance, however interestingly the effect is found negative in most of the cases. It indicates the claim that higher R\&D expenses cause poor financial performance in general. This result supports the findings of (Cazavan-Jeny, Jeanjean \& Joos, 2011) and oppose the findings of many other studies, for example, Lome, Heggeseth, \& Moen, (2016) and Jirásek, (2017). However, this result is subject to further analysis of threshold level, asset class and sector-sensitivity. However, inconsistency of the results 
indicates the heterogeneity among the firms in term of asset class and nature of sectors. It also supports the possibility of multiple regimes in focus variables.

\section{SECTOR ANALYSIS}

While aggregate analysis of financial performance offers an inclusive understanding of the effects of R\&D expenditures, a further sectoral analysis is able to give a more comprehensive understanding on the issue according to each industrial sector. There is a possibility of sector-specific growth, hence, there is a need to look at sector-specific sensitiveness (Sehrawat \& Giri, 2017). It has been recognised that the impact of R\&D activities varies across sectors and industries; where larger firms are better able to exploit the outcomes of R\&D activities, and firms in high-tech industries put much more emphasis on R\&D activities as compared to firms in low-tech industries (Schimke \& Brenner, 2014). A large collection of heterogenous firms may also introduce statistical regularities that are only the result of the aggregation procedure (e.g., via Central Limit Theorem); however, such aggregate analyses may lead to ambiguous conclusions (Bottazzi, \& Secchi, 2003).

The sectoral differences in the coupling of revenues to outputs also imply greater pressure to improve performance in for-profit sectors (Kalleberg, Marsden, Reynolds, \& Knoke, 2006). It is important to note that the stride for profit and related activities fluctuate for sectors; for instance, financial, materials, and telecommunication service sectors are more volatile than healthcare, energy and consumer staples sectors (Bottazzi \& Secchi, 2003). Innovation activities in some service sectors such as telecommunications, transports and finance are associated with the establishment of expensive technological infrastructures, which require large financial resources and high demand. Consequently, for firms in these sectors, past economic performances might be more relevant as a basis for their overall financial commitment to innovation (Cainelli, Evangelista, \& Savona, 2005).

Hence, there is the existence of widespread heterogeneity within each class and within each sector, as the production processes in quite diverse ways, and such heterogeneity does not occur with the same characteristics across industries (Bottazzi, Secchi, \& Tamagni, 2007). Subsequently, such sectoral growth disproportionately harms industries that are either financially dependent or R\&D-intensive (Cecchetti \& Kharroubi, 2012). In reality, sectoral differences in dividend yields, capitalisations, and number of firms admitted to the sector accounted for more than two-third of the changes in market share. (Siegel \& Schwartz, 2006). Therefore, for the existence of sectoral specificities in business operation, the 'pooling' of firms operating in different industrial sectors may conceal the specific characteristics of the dynamics of firms operating in different sectors (Bottazzi \& Secchi, 2003). This calls for the need for data disaggregation to make more meaningful analysis.

The whole data samples are split into 10 sectors, followed by S\&P methodology.

TABLE 7

SECTORAL CODE

\begin{tabular}{lc}
\hline Sector Name & Code \\
\hline Consumer Discretionary & 1 \\
Consumer Staples & 2 \\
Energy & 3 \\
Financials & 4 \\
Health Care & 5 \\
Industrials & 6 \\
Information Technology & 7 \\
Materials & 8 \\
Telecommunication Services & 9 \\
Utilities & 10 \\
\hline
\end{tabular}


TABLE 8

SECTOR: CONSUMER DISCRETIONARY

\begin{tabular}{lcc}
\hline & ROA & ROE \\
\hline & RDE/OPI & RDE/OPI \\
\hline L.ROA & 0.0358 & \\
\hline L.ROE & $(1.49)$ & \\
& & $0.108^{*}$ \\
LAST & & $(2.30)$ \\
& $-3.135^{* * *}$ & $-12.93^{* * *}$ \\
LNEI & $(-16.23)$ & $(-6.36)$ \\
& $1.548^{* * *}$ & $11.85^{* * *}$ \\
LEBI & $(5.95)$ & $(3.75)$ \\
& $1.762^{* * *}$ & 0.940 \\
NEI & $(5.67)$ & $(0.24)$ \\
& $0.00202^{*}$ & -0.0133 \\
OPI & $(2.36)$ & $(-1.29)$ \\
& $-0.00176^{* *}$ & 0.00540 \\
PRI & $(-2.75)$ & $(0.71)$ \\
& 0.00247 & 0.0420 \\
SAL & $(0.59)$ & $(0.93)$ \\
& 0.0000843 & 0.000391 \\
Constant & $(1.28)$ & $(0.52)$ \\
& $12.18^{* * *}$ & $58.88^{* * *}$ \\
\hline Observations & $(18.18)$ & $(8.46)$ \\
\hline
\end{tabular}

Given that the GMM standard errors are downward biased, robust standard errors are recommended. A robust version of the Sargan test however is available in STATA after specifying vce(robust). Given the limitations associated with the relatively short time span covered in our panel data set, we do not include any time trend component. Tests of joint significance are conducted but not reported. In line with the arbitrary rule of thumb suggested by Roodman (2009), the number of instruments doesn't the individual units (number of groups) in the panel suggesting potential problems of instrument proliferation are not apparent.

In table 8, sectoral analysis for Consumer Discretionary sector, estimation cannot be computed for R\&D expenses because of missing data. 


\section{TABLE 9}

\section{SECTOR: CONSUMER STAPLES}

\begin{tabular}{lcccc}
\hline & ROA & ROE & ROA & ROE \\
\hline L.ROA & RDE & RDE & RDE/OPI & RDE/OPI \\
L.ROE & $0.126^{* * *}$ & & $0.109^{* * *}$ & \\
& $(6.21)$ & & $(5.41)$ & -0.0266 \\
RDE & & -0.0545 & & $(-0.59)$ \\
& -0.000199 & $-0.459^{* * *}$ & & \\
RDEOPI & $(-1.22)$ & $(-4.89)$ & & \\
& & & $1.200^{* * *}$ & -183.1 \\
LAST & & & $(4.00)$ & $(-1.23)$ \\
& $-4.430^{* * *}$ & -106.8 & $-4.721^{* * *}$ & -100.4 \\
LNEI & $(-21.13)$ & $(-1.18)$ & $(-22.06)$ & $(-1.06)$ \\
& $1.253^{* * *}$ & -0.500 & $1.233^{* * *}$ & 26.03 \\
LEBI & $(9.45)$ & $(-0.01)$ & $(9.60)$ & $(0.44)$ \\
& $2.604^{* * *}$ & 51.59 & $3.133^{* * *}$ & -33.72 \\
NEI & $(13.07)$ & $(0.58)$ & $(13.53)$ & $(-0.31)$ \\
& 0.000424 & 0.0237 & $0.000471^{*}$ & -0.0414 \\
OPI & $(1.94)$ & $(0.24)$ & $(2.23)$ & $(-0.42)$ \\
& $-0.000391^{*}$ & -0.0664 & - & -0.0446 \\
& & & $0.000366^{*}$ & \\
PRI & $(-2.37)$ & $(-0.88)$ & $(-2.30)$ & $(-0.58)$ \\
& $0.00726^{*}$ & -0.793 & $0.00733^{*}$ & 0.130 \\
SAL & $(2.30)$ & $(-0.61)$ & $(2.41)$ & $(0.10)$ \\
& $0.0000439^{*}$ & $0.0324^{* * *}$ & 0.0000223 & $0.0209^{* *}$ \\
Constant & $(2.53)$ & $(4.36)$ & $(1.40)$ & $(2.94)$ \\
& $19.99^{* * *}$ & 528.5 & $18.99^{* * *}$ & 859.8 \\
Observations & $(14.62)$ & $(0.89)$ & $(14.06)$ & $(1.37)$ \\
\hline & 297 & 295 & 297 & 295 \\
\hline & & & &
\end{tabular}

Given that the GMM standard errors are downward biased, robust standard errors are recommended. A robust version of the Sargan test however is available in STATA after specifying vce(robust). Given the limitations associated with the relatively short time span covered in our panel data set, we do not include any time trend component. Tests of joint significance are conducted but not reported. In line with the arbitrary rule of thumb suggested by Roodman (2009), the number of instruments doesn't the individual units (number of groups) in the panel suggesting potential problems of instrument proliferation are not apparent.

In case of consumer staples sector Table 9, RDE is statistically significant to ROE, but not ROA, and $\mathrm{RDE} / \mathrm{OPI}$ is significant to ROA but not to ROE. Interesting point here is that RDE is positively correlated with ROE but RDE/OPI is negatively correlated with ROA. A significant difference is noticed in ROA and ROE that refers to the significant impact of capital structure (debt -equity ratio) in R\&D expenses and financial performance nexus. Also, there could be an existence of threshold point that divides the samples into two regimes and the effect is totally opposite in different regimes. 
TABLE 10

\section{SECTOR: ENERGY}

\begin{tabular}{|c|c|c|c|c|}
\hline & ROA & ROE & ROA & ROE \\
\hline & RDE & RDE & RDE/OPI & RDE/OPI \\
\hline L.ROA & $\begin{array}{l}-0.0325 \\
(-1.04)\end{array}$ & & $\begin{array}{l}-0.0265 \\
(-0.85)\end{array}$ & \\
\hline L.ROE & & $\begin{array}{c}0.0884^{*} \\
(2.20)\end{array}$ & & $\begin{array}{c}0.0959^{*} \\
(2.36)\end{array}$ \\
\hline $\mathrm{RDE}$ & $\begin{array}{c}-0.00422 \\
(-0.89)\end{array}$ & $\begin{array}{c}-0.0118 \\
(-1.08)\end{array}$ & & \\
\hline RDEOPI & & & $\begin{array}{l}4.298 \\
(0.39)\end{array}$ & $\begin{array}{l}10.24 \\
(0.40)\end{array}$ \\
\hline LAST & $\begin{array}{l}-4.647^{* * *} \\
(-23.61)\end{array}$ & $\begin{array}{l}-6.095^{* * *} \\
(-13.62)\end{array}$ & $\begin{array}{l}-4.757^{* * *} \\
(-20.25)\end{array}$ & $\begin{array}{l}-6.395^{* * *} \\
(-11.74)\end{array}$ \\
\hline LNEI & $\begin{array}{c}2.131^{* * *} \\
(3.56)\end{array}$ & $\begin{array}{l}0.766 \\
(0.55)\end{array}$ & $\begin{array}{c}2.080^{* * *} \\
(3.38)\end{array}$ & $\begin{array}{l}0.649 \\
(0.45)\end{array}$ \\
\hline LEBI & $\begin{array}{c}3.113^{* * *} \\
(4.75)\end{array}$ & $\begin{array}{c}5.294^{* * *} \\
(3.50)\end{array}$ & $\begin{array}{c}3.225^{* * *} \\
(4.64)\end{array}$ & $\begin{array}{c}5.595^{* * *} \\
(3.46)\end{array}$ \\
\hline NEI & $\begin{array}{c}0.00227^{* * *} \\
(3.50)\end{array}$ & $\begin{array}{c}0.00638^{* * *} \\
(4.24)\end{array}$ & $\begin{array}{c}0.00211^{* *} \\
(3.24)\end{array}$ & $\begin{array}{c}0.00595^{* * *} \\
(3.91)\end{array}$ \\
\hline OPI & $\begin{array}{c}-0.00203^{* * *} \\
(-3.73)\end{array}$ & $\begin{array}{c}-0.00269^{*} \\
(-2.19)\end{array}$ & $\begin{array}{c}-0.00190^{* * *} \\
(-3.43)\end{array}$ & $\begin{array}{c}-0.00238 \\
(-1.88)\end{array}$ \\
\hline PRI & $\begin{array}{c}0.00290 \\
(0.29)\end{array}$ & $\begin{array}{l}0.0272 \\
(1.14)\end{array}$ & $\begin{array}{c}0.00173 \\
(0.17)\end{array}$ & $\begin{array}{l}0.0241 \\
(0.98)\end{array}$ \\
\hline SAL & 0.00000957 & $\begin{array}{c}- \\
0.00000737 \\
(-0.49)\end{array}$ & 0.00000694 & $\begin{array}{c}- \\
0.0000143 \\
(-0.99)\end{array}$ \\
\hline Constant & $\begin{array}{l}15.76^{* * *} \\
(10.86)\end{array}$ & $\begin{array}{c}25.20^{* * *} \\
(7.44)\end{array}$ & $\begin{array}{l}16.16^{* * *} \\
(11.04)\end{array}$ & $\begin{array}{c}26.25^{* * *} \\
(7.58)\end{array}$ \\
\hline Observations & 36 & 36 & 36 & 36 \\
\hline
\end{tabular}

Given that the GMM standard errors are downward biased, robust standard errors are recommended. A robust version of the Sargan test however is available in STATA after specifying vce(robust). Given the limitations associated with the relatively short time span covered in our panel data set, we do not include any time trend component. Tests of joint significance are conducted but not reported. In line with the arbitrary rule of thumb suggested by Roodman (2009), the number of instruments doesn't the individual units (number of groups) in the panel suggesting potential problems of instrument proliferation are not apparent.

In energy sector table 10 , both of the proxies of $R \& D$ expenses is found statistically insignificant to financial performance. Results reveal that, R \& D expenses does not have any impact on firms' financial performance. However, result could be different in different asset class and also in different regimes. 
TABLE 11

SECTOR: FINANCIALS

\begin{tabular}{lcc}
\hline & ROA & ROE \\
\hline L.ROA & $0.128^{* * *}$ & RDE/OPI \\
\hline L.ROE & $(3.76)$ & \\
& & $1.086^{* * *}$ \\
& $(-16.87)$ & $(-3.11)$ \\
LNEI & 0.367 & $-4.769^{*}$ \\
& $(1.30)$ & $(-2.28)$ \\
LEBI & $7.103^{* * *}$ & $13.01^{* *}$ \\
& $(13.02)$ & $(2.94)$ \\
NEI & & \\
& $0.00280^{* * *}$ & $0.0144^{* * *}$ \\
& $(9.50)$ & $(6.42)$ \\
OPI & $-0.00186^{* * *}$ & -0.00190 \\
& $(-8.09)$ & $(-1.02)$ \\
PRI & $0.0211^{* *}$ & -0.0508 \\
& $(3.25)$ & $(-0.94)$ \\
SAL & & \\
Constant & $0.0000970^{* * *}$ & 0.0000828 \\
& $(3.32)$ & $(0.34)$ \\
Observations & $26.66^{* * *}$ & $29.98^{* *}$ \\
& $(19.60)$ & $(3.12)$ \\
\hline
\end{tabular}

Given that the GMM standard errors are downward biased, robust standard errors are recommended. A robust version of the Sargan test however is available in STATA after specifying vce(robust). Given the limitations associated with the relatively short time span covered in our panel data set, we do not include any time trend component. Tests of joint significance are conducted but not reported. In line with the arbitrary rule of thumb suggested by Roodman (2009), the number of instruments doesn't the individual units (number of groups) in the panel suggesting potential problems of instrument proliferation are not apparent.

In financial sector, table 11, estimation cannot be computed for RDE because of insufficient data. Although this result can be different with different terms. 
TABLE 12

SECTOR: HEALTH CARE

\begin{tabular}{|c|c|c|c|c|}
\hline & ROA & ROE & ROA & ROE \\
\hline & RDE & RDE & RDE/OPI & RDE/OPI \\
\hline L.ROA & & & $-0.0626^{* * *}$ & \\
\hline & & & $(-4.12)$ & \\
\hline L.ROE & $\begin{array}{l}1.061^{* * *} \\
(18.60)\end{array}$ & $\begin{array}{l}1.061^{* * *} \\
(18.60)\end{array}$ & & $\begin{array}{c}-0.0844^{* * *} \\
(-7.63)\end{array}$ \\
\hline LAST & $\begin{array}{l}(1.16)^{* *} \\
-10.35^{* *} \\
(-2.80)\end{array}$ & $\begin{array}{l}(1.16) \\
-10.35^{* *} \\
(-2.80)\end{array}$ & $\begin{array}{c}-3.922^{* * *} \\
(-9.32)\end{array}$ & $\begin{array}{l}-12.41^{* * *} \\
(-10.15)\end{array}$ \\
\hline LNEI & $\begin{array}{l}-4.553^{*} \\
(-2.17)\end{array}$ & $\begin{array}{l}-4.553^{*} \\
(-2.17)\end{array}$ & $\begin{array}{l}0.492 \\
(1.56)\end{array}$ & $\begin{array}{c}2.646^{* *} \\
(2.58)\end{array}$ \\
\hline LEBI & $\begin{array}{l}11.95^{* *} \\
(2.64)\end{array}$ & $\begin{array}{l}11.95^{* *} \\
(2.64)\end{array}$ & $\begin{array}{c}2.569^{* * *} \\
(4.93)\end{array}$ & $\begin{array}{c}6.019^{* * *} \\
(3.95)\end{array}$ \\
\hline NEI & $\begin{array}{c}0.0142^{* * *} \\
(6.33)\end{array}$ & $\begin{array}{c}0.0142^{* * *} \\
(6.33)\end{array}$ & $\begin{array}{c}0.00332^{* * *} \\
(25.00)\end{array}$ & $\begin{array}{c}0.00951^{* * *} \\
\quad(6.73)\end{array}$ \\
\hline OPI & $\begin{array}{c}-0.00156 \\
(-0.83)\end{array}$ & $\begin{array}{c}-0.00156 \\
(-0.83)\end{array}$ & $\begin{array}{c}-0.00196^{* * *} \\
(-6.29)\end{array}$ & $\begin{array}{c}-0.00363^{* *} \\
(-2.76)\end{array}$ \\
\hline PRI & $\begin{array}{c}-0.0621 \\
(-1.13)\end{array}$ & $\begin{array}{c}-0.0621 \\
(-1.13)\end{array}$ & $\begin{array}{c}0.0330^{*} \\
(1.97)\end{array}$ & $\begin{array}{c}0.215^{* * *} \\
(3.40)\end{array}$ \\
\hline SAL & $\begin{array}{c}0.0000312 \\
\quad(0.13)\end{array}$ & $\begin{array}{l}0.0000312 \\
(0.13)\end{array}$ & $\begin{array}{c}0.000161^{* * *} \\
\quad(3.38)\end{array}$ & $\begin{array}{c}0.000669^{* * *} \\
(3.39)\end{array}$ \\
\hline Constant & $\begin{array}{c}28.54^{* *} \\
(2.94)\end{array}$ & $\begin{array}{c}28.54^{* *} \\
(2.94)\end{array}$ & $\begin{array}{c}19.47^{* * *} \\
(9.00) \\
\end{array}$ & $\begin{array}{c}63.92^{* * *} \\
(10.55)\end{array}$ \\
\hline Observations & 100 & 100 & 98 & 86 \\
\hline
\end{tabular}

Given that the GMM standard errors are downward biased, robust standard errors are recommended. A robust version of the Sargan test however is available in STATA after specifying vce(robust). Given the limitations associated with the relatively short time span covered in our panel data set, we do not include any time trend component. Tests of joint significance are conducted but not reported. In line with the arbitrary rule of thumb suggested by Roodman (2009), the number of instruments doesn't the individual units (number of groups) in the panel suggesting potential problems of instrument proliferation are not apparent.

In Health care sector, table 12, the analysis failed to apply GMM technique to compute the values for industrials sectors because of inadequate data. 


\section{TABLE 13}

\section{SECTOR: INFORMATION TECHNOLOGY}

\begin{tabular}{|c|c|c|c|c|}
\hline & ROA & $\mathrm{ROE}$ & ROA & $\mathrm{ROE}$ \\
\hline & RDE & $\mathrm{RDE}$ & RDE/OPI & RDE/OPI \\
\hline L.ROA & $\begin{array}{l}0.0123 \\
(0.18)\end{array}$ & & $\begin{array}{c}-0.00912 \\
(-0.13)\end{array}$ & \\
\hline L.ROE & & $\begin{array}{c}-0.0106 \\
(-0.19)\end{array}$ & & $\begin{array}{l}-0.0228 \\
(-0.40)\end{array}$ \\
\hline RDE & $\begin{array}{c}-0.0159^{* *} \\
(-2.81)\end{array}$ & $\begin{array}{c}-0.0416^{* * *} \\
(-3.45)\end{array}$ & & \\
\hline RDEOPI & & & $\begin{array}{l}-20.70^{* *} \\
(-2.60)\end{array}$ & $\begin{array}{l}-50.59^{* *} \\
(-2.95)\end{array}$ \\
\hline LAST & $\begin{array}{l}-0.342 \\
(-0.23)\end{array}$ & $\begin{array}{l}4.248 \\
(1.37)\end{array}$ & $\begin{array}{l}-0.812 \\
(-0.53)\end{array}$ & $\begin{array}{l}3.368 \\
(1.06)\end{array}$ \\
\hline LNEI & $\begin{array}{l}0.418 \\
(1.66)\end{array}$ & $\begin{array}{l}0.887 \\
(1.65)\end{array}$ & $\begin{array}{l}0.638^{* *} \\
(2.65)\end{array}$ & $\begin{array}{l}1.476^{* *} \\
(2.84)\end{array}$ \\
\hline LEBI & $\begin{array}{l}2.514^{* *} \\
(2.62)\end{array}$ & $\begin{array}{c}8.132^{* * *} \\
(3.92)\end{array}$ & $\begin{array}{l}0.656 \\
(0.61)\end{array}$ & $\begin{array}{l}3.357 \\
(1.41)\end{array}$ \\
\hline NEI & $\begin{array}{c}0.00359^{* * *} \\
(4.23)\end{array}$ & $\begin{array}{c}0.0100^{* * *} \\
(5.45)\end{array}$ & $\begin{array}{c}0.00350^{* * *} \\
(4.06)\end{array}$ & $\begin{array}{c}0.00986^{* * *} \\
(5.23)\end{array}$ \\
\hline OPI & $\begin{array}{c}-0.00122 \\
(-1.45)\end{array}$ & $\begin{array}{c}-0.00426^{*} \\
(-2.32)\end{array}$ & $\begin{array}{c}-0.000803 \\
(-0.92)\end{array}$ & $\begin{array}{c}-0.00317 \\
(-1.66)\end{array}$ \\
\hline PRI & $\begin{array}{c}-0.0342 \\
(-1.49)\end{array}$ & $\begin{array}{c}-0.0710 \\
(-1.44)\end{array}$ & $\begin{array}{c}-0.0241 \\
(-1.04)\end{array}$ & $\begin{array}{c}-0.0450 \\
(-0.90)\end{array}$ \\
\hline SAL & -0.000132 & $\begin{array}{c}- \\
0.000696^{*} \\
(-2.33)\end{array}$ & -0.000180 & $\begin{array}{c}- \\
0.000846^{* *} \\
(-2.82)\end{array}$ \\
\hline Constant & $\begin{array}{l}-7.555 \\
(-0.61)\end{array}$ & $\begin{array}{c}-72.58^{* *} \\
(-2.81)\end{array}$ & $\begin{array}{l}7.700 \\
(0.57)\end{array}$ & $\begin{array}{l}-36.79 \\
(-1.29)\end{array}$ \\
\hline Observations & 29 & 29 & 29 & 29 \\
\hline
\end{tabular}

Given that the GMM standard errors are downward biased, robust standard errors are recommended. A robust version of the Sargan test however is available in STATA after specifying vce(robust). Given the limitations associated with the relatively short time span covered in our panel data set, we do not include any time trend component. Tests of joint significance are conducted but not reported. In line with the arbitrary rule of thumb suggested by Roodman (2009), the number of instruments doesn't the individual units (number of groups) in the panel suggesting potential problems of instrument proliferation are not apparent.

In software technology sector, Table 13 , both proxies of $R \& D$ expenses is found highly significant and negatively correlated with financial performance. It refers that more expenditures of R\&D will negatively affect the financial performance of the firms in software technology sector. 
TABLE 14

SECTOR: MATERIALS

\begin{tabular}{|c|c|c|c|c|}
\hline & ROA & ROE & $\mathrm{ROA}$ & ROE \\
\hline & RDE & RDE & RDE/OPI & $\mathrm{RDE} / \mathrm{OPI}$ \\
\hline L.ROA & $\begin{array}{c}0.146^{* * *} \\
(7.63)\end{array}$ & & $\begin{array}{c}0.0144 \\
(0.95)\end{array}$ & \\
\hline \multirow[t]{2}{*}{ L.ROE } & & $\begin{array}{c}0.156^{* * *} \\
(6.87)\end{array}$ & & $\begin{array}{c}0.905^{* * *} \\
(4.22)\end{array}$ \\
\hline & $(-21.84)$ & $(-12.81)$ & $(-25.77)$ & $(2.23)$ \\
\hline LNEI & $\begin{array}{l}1.111^{* *} \\
(3.01)\end{array}$ & $\begin{array}{c}-7.741^{* * *} \\
(-7.24)\end{array}$ & $\begin{array}{l}0.503 \\
(1.35)\end{array}$ & $\begin{array}{l}12.12 \\
(0.99)\end{array}$ \\
\hline LEBI & $\begin{array}{l}5.631^{* * *} \\
(12.07)\end{array}$ & $\begin{array}{l}19.75^{* * *} \\
(14.06)\end{array}$ & $\begin{array}{l}7.650^{* * *} \\
(14.91)\end{array}$ & $\begin{array}{l}-33.18 \\
(-1.95)\end{array}$ \\
\hline NEI & $\begin{array}{c}0.00830^{* * *} \\
(4.79)\end{array}$ & $\begin{array}{c}0.0270^{* * *} \\
(5.34)\end{array}$ & $\begin{array}{c}0.0196^{* * *} \\
(30.71)\end{array}$ & $\begin{array}{c}-0.00320 \\
(-0.15)\end{array}$ \\
\hline OPI & $\begin{array}{c}- \\
0.00340^{* * *} \\
(-3.59)\end{array}$ & $\begin{array}{c}-0.0114^{* * *} \\
(-3.98)\end{array}$ & $\begin{array}{c}- \\
0.00895^{* * *} \\
(-15.74)\end{array}$ & $0.0761^{* * *}$ \\
\hline PRI & $\begin{array}{c}-0.00466 \\
(-0.39)\end{array}$ & $\begin{array}{c}-0.0296 \\
(-0.91)\end{array}$ & $\begin{array}{c}-0.0256^{*} \\
(-2.38)\end{array}$ & $\begin{array}{l}0.878^{*} \\
(2.27)\end{array}$ \\
\hline SAL & $\begin{array}{c}- \\
0.0000308 \\
(-0.49)\end{array}$ & $\begin{array}{c}0.0000651 \\
(0.36)\end{array}$ & $\begin{array}{c}- \\
0.0000251 \\
(-0.40)\end{array}$ & $\begin{array}{c}- \\
0.0110^{\text {*** }} \\
(-5.28)\end{array}$ \\
\hline Constant & $\begin{array}{l}18.68^{* * *} \\
(19.29)\end{array}$ & $\begin{array}{c}21.46^{* * *} \\
(8.08)\end{array}$ & $\begin{array}{l}19.60^{* * *} \\
(21.64)\end{array}$ & $\begin{array}{l}-9.907 \\
(-0.35) \\
\end{array}$ \\
\hline Observations & 136 & 136 & 178 & 175 \\
\hline
\end{tabular}

Given that the GMM standard errors are downward biased, robust standard errors are recommended. A robust version of the Sargan test however is available in STATA after specifying vce(robust). Given the limitations associated with the relatively short time span covered in our panel data set, we do not include any time trend component. Tests of joint significance are conducted but not reported. In line with the arbitrary rule of thumb suggested by Roodman (2009), the number of instruments doesn't the individual units (number of groups) in the panel suggesting potential problems of instrument proliferation are not apparent. 
TABLE 15

SECTOR: TELECOMMUNICATION SERVICES

\begin{tabular}{lcccc}
\hline & ROA & ROE & ROA & ROE \\
\hline L.ROA & RDE & RDE & RDE/OPI & RDE/OPI \\
& 0.0894 & & $0.0745^{*}$ & \\
L.ROE & $(0.78)$ & & $(2.01)$ & 0.0848 \\
RDE & & 0.00560 & & $(1.85)$ \\
& -0.0147 & 0.308 & & \\
RDEOPI & $(-0.39)$ & $(1.26)$ & & \\
& & & 18.35 & $319.2^{* * *}$ \\
& & & $(1.19)$ & $(6.93)$ \\
LNEI & $(-5.28)$ & $(-2.42)$ & $(-15.48)$ & $(-4.04)$ \\
& 1.135 & 15.42 & -0.451 & $4.175^{* *}$ \\
LEBI & $(0.51)$ & $(1.08)$ & $(-1.46)$ & $(2.89)$ \\
& $20.09^{* * *}$ & 34.43 & $11.01^{* * *}$ & $7.627^{*}$ \\
NEI & $(3.88)$ & $(1.13)$ & $(13.80)$ & $(2.24)$ \\
& $0.0330^{*}$ & -0.0841 & $0.0178^{* * *}$ & 0.0174 \\
OPI & $(1.97)$ & $(-0.81)$ & $(7.28)$ & $(1.48)$ \\
& - & -0.0664 & $-0.00538^{*}$ & -0.0102 \\
& $0.0361^{*}$ & & & \\
PRI & $(-2.41)$ & $(-0.76)$ & $(-2.37)$ & $(-0.96)$ \\
& 0.00407 & 0.0131 & $0.0224^{* *}$ & 0.000534 \\
SAL & $(0.15)$ & $(0.07)$ & $(3.26)$ & $(0.02)$ \\
& 0.00164 & 0.0176 & - & - \\
& & & $0.00105^{* * * *}$ & 0.0000559 \\
Constant & $(1.16)$ & $(1.89)$ & $(-3.70)$ & $(-0.04)$ \\
& -0.0791 & 20.76 & $22.86^{* * *}$ & $38.46^{* * *}$ \\
Observations & $(-0.00)$ & $(0.20)$ & $(10.75)$ & $(3.75)$ \\
\hline & 29 & 29 & 128 & 128 \\
\hline & & & &
\end{tabular}

Given that the GMM standard errors are downward biased, robust standard errors are recommended. A robust version of the Sargan test however is available in STATA after specifying vce(robust). Given the limitations associated with the relatively short time span covered in our panel data set, we do not include any time trend component. Tests of joint significance are conducted but not reported. In line with the arbitrary rule of thumb suggested by Roodman (2009), the number of instruments doesn't the individual units (number of groups) in the panel suggesting potential problems of instrument proliferation are not apparent.

Unlike many other sectors, for telecommunication services, R\&D expenses ratio is found positively significant. Though other proxies show insignificant result. Results reveal that higher expenditures in $\mathrm{R} \& \mathrm{D}$ expenses of the firms in telecommunication services will create better financial performance. 
TABLE 16

SECTOR: UTILITIES

\begin{tabular}{|c|c|c|c|c|}
\hline & ROA & $\mathrm{ROE}$ & ROA & $\mathrm{ROE}$ \\
\hline & RDE & $\mathrm{RDE}$ & $\mathrm{RDE} / \mathrm{OPI}$ & RDE/OPI \\
\hline L.ROA & $\begin{array}{c}0.201^{* * *} \\
(5.84)\end{array}$ & & $\begin{array}{c}0.201^{* * *} \\
(5.90)\end{array}$ & \\
\hline L.ROE & & $\begin{array}{c}0.130^{* * *} \\
(3.62)\end{array}$ & & $\begin{array}{c}0.123^{* * *} \\
(3.45)\end{array}$ \\
\hline RDE & $\begin{array}{c}0.00333 \\
(0.71)\end{array}$ & $\begin{array}{c}0.00858 \\
(1.05)\end{array}$ & & \\
\hline RDEOPI & & & $\begin{array}{l}1.065 \\
(1.29)\end{array}$ & $\begin{array}{c}5.261^{* * *} \\
(3.64)\end{array}$ \\
\hline LAST & $\begin{array}{c}-9.185^{* * *} \\
(-17.55)\end{array}$ & $\begin{array}{c}-14.75^{* * *} \\
(-16.31)\end{array}$ & $\begin{array}{c}-9.573^{* * *} \\
(-15.54)\end{array}$ & $\begin{array}{c}-16.78^{* * *} \\
(-15.78)\end{array}$ \\
\hline LNEI & $\begin{array}{c}5.262^{* * *} \\
(7.57)\end{array}$ & $\begin{array}{c}7.218^{* * *} \\
(5.86)\end{array}$ & $\begin{array}{c}5.428^{* * * *} \\
(7.73)\end{array}$ & $\begin{array}{c}7.946^{* * * *} \\
(6.43)\end{array}$ \\
\hline LEBI & $\begin{array}{c}2.600^{* *} \\
(3.27)\end{array}$ & $\begin{array}{c}7.894^{* * *} \\
(5.21)\end{array}$ & $\begin{array}{c}2.808^{* * *} \\
(3.48)\end{array}$ & $\begin{array}{c}8.852^{* * * *} \\
(5.84)\end{array}$ \\
\hline NEI & $\begin{array}{c}0.0168^{* * *} \\
(3.44)\end{array}$ & $\begin{array}{c}0.0191^{*} \\
(2.44)\end{array}$ & $\begin{array}{c}0.0157^{* *} \\
(3.15)\end{array}$ & $\begin{array}{l}0.0130 \\
(1.63)\end{array}$ \\
\hline OPI & $\begin{array}{c}0.0155^{\text {*** }} \\
(-3.56)\end{array}$ & $\begin{array}{c}- \\
0.0259^{* * *} \\
(-3.55)\end{array}$ & $-0.0144^{* *}$ & $-0.0182^{*}$ \\
\hline PRI & $\begin{array}{c}0.0354 \\
(1.95)\end{array}$ & $\begin{array}{c}0.0681^{*} \\
(2.17)\end{array}$ & $\begin{array}{c}0.0357^{*} \\
(1.98)\end{array}$ & $\begin{array}{c}0.0723^{*} \\
(2.33)\end{array}$ \\
\hline SAL & $\begin{array}{c}0.00150 \\
(1.04)\end{array}$ & $\begin{array}{c}0.00227 \\
(0.89)\end{array}$ & $\begin{array}{c}0.00202^{*} \\
(2.23)\end{array}$ & $\begin{array}{c}0.00284 \\
(1.79)\end{array}$ \\
\hline Constant & $\begin{array}{l}34.81^{* * *} \\
(17.13)\end{array}$ & $\begin{array}{c}44.08^{* * *} \\
(11.85)\end{array}$ & $\begin{array}{l}34.88^{* * *} \\
(17.48)\end{array}$ & $\begin{array}{l}46.02^{* * *} \\
(12.54)\end{array}$ \\
\hline Observations & 104 & 102 & 104 & 102 \\
\hline
\end{tabular}

Given that the GMM standard errors are downward biased, robust standard errors are recommended. A robust version of the Sargan test however is available in STATA after specifying vce(robust). Given the limitations associated with the relatively short time span covered in our panel data set, we do not include any time trend component. Tests of joint significance are conducted but not reported. In line with the arbitrary rule of thumb suggested by Roodman (2009), the number of instruments doesn't the individual units (number of groups) in the panel suggesting potential problems of instrument proliferation are not apparent.

Statistical result in utilities sectors is found to be quite different from other sectors. One obvious reason behind such findings is that utilities do not require much intellectual assets rather it is essential for people. However, R\&D expenses is found to be positively significant with the firms' financial performance mean that more R\&D expenses improve financial performance, perhaps by finding out how to provide services in a better way. So, firms of utilities sector can concentrate on this and spend some on R\&D activities. The sectoral analysis supports the findings of many other previous studies (Pandit et at., 2009; Dave et al., 2013; Schimke \& Brenner, 2014). 
TABLE 17

SECTORAL VARIATIONS IN CONTEXT OF R\&D EXPENDITURES-FINANCIAL PERFORMANCE NEXUS

\begin{tabular}{|c|c|c|c|c|}
\hline & & & Findings & Comment \\
\hline \multirow{4}{*}{$\begin{array}{l}\text { Sector 1: Consumer } \\
\text { Discretionary }\end{array}$} & \multirow[b]{2}{*}{$\mathrm{RDE}$} & ROA & & \multirow{25}{*}{$\begin{array}{l}\text { Because of the inadequacy of } \\
\text { data, value could not be } \\
\text { computed for few sectors. } \\
\text { However, significant difference } \\
\text { is found among the sectors. } \\
\text { While evidence is found that } \\
\text { R\&D expenses has positive and } \\
\text { significant Impact on financial } \\
\text { performance of consumer } \\
\text { staple sectors, telcom sector } \\
\text { and utilities sectors, it is } \\
\text { negatively significant for } \\
\text { Information technology sectors. } \\
\text { However, this result subject to } \\
\text { the threshold level and also }\end{array}$} \\
\hline & & $\mathrm{ROE}$ & & \\
\hline & \multirow[b]{2}{*}{ RDE/OPI } & ROA & & \\
\hline & & ROE & & \\
\hline \multirow{4}{*}{$\begin{array}{l}\text { Sector 2: Consumer } \\
\text { Staples }\end{array}$} & \multirow[b]{2}{*}{$\mathrm{RDE}$} & ROA, & Not-significant & \\
\hline & & ROE & $\begin{array}{l}\text { Significant, } \\
\text { positive }\end{array}$ & \\
\hline & RDE/OPI & ROA & $\begin{array}{l}\text { Significant, } \\
\text { positive }\end{array}$ & \\
\hline & & $\mathrm{ROE}$ & Not-significant & \\
\hline Sector 3: Energy & & ROA, & Not-significant & \\
\hline & RDE & ROE & Not-significant & \\
\hline & & ROA & Not-significant & \\
\hline & RDE/OPI & ROE & Not-significant & \\
\hline Sector 4: Financials & & ROA, & & \\
\hline & RDE & ROE & & \\
\hline & & ROA & & \\
\hline & RDE/OPI & ROE & & \\
\hline Sector 5: Health & & ROA, & & \\
\hline & RDE & ROE & & \\
\hline & & ROA & & \\
\hline & RDE/OPI & $\mathrm{ROE}$ & & \\
\hline Sector 6: Industrials & RDE & The a & failed apply GMM & \\
\hline & $\mathrm{RDE} / \mathrm{OPI}$ & $\begin{array}{l}\text { technic } \\
\text { for inc } \\
\text { inadeq }\end{array}$ & $\begin{array}{l}\text { compute the values } \\
\text { sectors because of } \\
\text { a. }\end{array}$ & \\
\hline $\begin{array}{l}\text { Sector 7: } \\
\text { Information }\end{array}$ & RDE & ROA, & $\begin{array}{l}\text { Significant, } \\
\text { Negative }\end{array}$ & \\
\hline recnnorogy & & ROE & $\begin{array}{l}\text { Significant, } \\
\text { Negative }\end{array}$ & \\
\hline & & ROA & $\begin{array}{l}\text { Significant, } \\
\text { Negative }\end{array}$ & \\
\hline
\end{tabular}




\begin{tabular}{|c|c|c|c|c|}
\hline & & & Findings & Comment \\
\hline & RDE/OPI & $\mathrm{ROE}$ & $\begin{array}{l}\text { Significant, } \\
\text { Negative }\end{array}$ & \\
\hline \multirow[t]{4}{*}{ Sector 8: Materials } & \multirow[b]{2}{*}{ RDE } & ROA, & & \\
\hline & & ROE & & \\
\hline & \multirow[b]{2}{*}{ RDE/OPI } & ROA & & \\
\hline & & ROE & & \\
\hline \multirow{4}{*}{$\begin{array}{l}\text { Sector } 9 \text { : } \\
\text { Telecommunication } \\
\text { Services }\end{array}$} & \multirow[t]{2}{*}{$\mathrm{RDE}$} & ROA, & Not-significant & \\
\hline & & ROE & Not-significant & \\
\hline & \multirow[b]{2}{*}{ RDE/OPI } & ROA & Not-significant & \\
\hline & & ROE & $\begin{array}{l}\text { Significant, } \\
\text { Positive }\end{array}$ & \\
\hline \multirow[t]{4}{*}{ Sector 10: Utilities } & \multirow[b]{2}{*}{ RDE } & ROA, & Not-significant & \\
\hline & & ROE & Not-significant & \\
\hline & \multirow[b]{2}{*}{ RDE/OPI } & ROA & Not-significant & \\
\hline & & ROE & $\begin{array}{l}\text { Significant, } \\
\text { Positive }\end{array}$ & \\
\hline
\end{tabular}

The current study intended to examine the relationship between R\&D expense and corporate financial performance. To do so, the study considers the ratio of R\&D expense and operating income besides considering R\&D expenses to measure the relationship. By employing the data from S\&P 500 companies over the period of 1979 to 2015, the study finds diverse outcomes concerning the relationship. Mostly, the R\&D expenses affect financial performance negatively. Moreover, the current study considers the financial strength endogeneity by investigating the influence of R\&D expenses on performance for the firms in dissimilar asset class. Through quantile regression analysis, significant difference is found in different quantiles of asset size. Besides, the study weighs up the non-linear nature of expenditure in R\&D activities, therefore, employs the threshold analysis. To attain comprehensive understanding the investigation further expands to sectoral analyses. Though because of the inadequacy of data, analyses were not possible to conduct for few sectors; however, significant difference in performance is found among the sectors. While the impact of R\&D expenses is positive and significant for consumer staple, telecom and utilities sectors, it is negatively significant for information technology.

The findings are also expected to help the financial managers to forecast the future return of a firm and also to measure the riskiness of financing and investment activities. Further, it is expected to aid the policy makers to settle on which sectors are worthy to be prioritized and how much supported to give in order to get the expected result in line with country's investment policy. Also notably, the study adds value to the academia by considering $R \& D$ expenses on corporate performance which is not clear in the existing literature. Besides answering some unsettled research problems and adding knowledge to the growing body of literature in this filed, the study unveils further avenue of research for academics.

The study endeavoured comprehensive analyses and fairly novel attempt to understand the nexus; nevertheless, it is not devoid of some limitations mostly owing to unavailability of adequate data. The dataset comprises only S\&P 500 companies which are predominantly large companies based on developed economy (i.e. the USA), thus leads to lack of generalizability of the findings for the companies around the globe. Also, in some cases sufficient sectoral data were not available and levied restrictions on 
analyses. Likewise, the study did not take into consideration the institutional and governance variables. Since significant difference is found in asset-equity structure of the companies, further analyses with such variables could have been more insightful. Correspondingly, the analyses do not expands to consider regional variations of the firms' spending in R\&D activities, thus the study does not provide how the relationship varies region-wise, i.e. how the developed country firms get benefits from R\&D expenses compared to developing ones. Hence, future research may consider new datasets and incorporate regional analyses by giving consideration for institutional and political variables which will stretch better generalizability of the research. Furthermore, study can be further extended by considering threshold and asset size effect for different sectors as the current finding is somewhat heterogeneous.

\section{ENDNOTES}

1. A data analysis software

2. Over-identification test

3. Auto-correlation test

\section{REFERENCES}

Bottazzi, G., \& Secchi, A. (2003). Common properties and sectoral specificities in the dynamics of US manufacturing companies. Review of Industrial Organization, 23(3-4), 217-232.

Bottazzi, G., Secchi, A., \& Tamagni, F. (2007). Productivity, profitability and financial fragility: empirical evidence from Italian business firms. Retrieved from

Cainelli, G., Evangelista, R., \& Savona, M. (2005). Innovation and economic performance in services: a firm-level analysis. Cambridge Journal of Economics, 30(3), 435-458.

Cazavan-Jeny, A., Jeanjean, T., \& Joos, P. (2011). Accounting choice and future performance: The case of R\&D accounting in France. Journal of Accounting and Public Policy, 30(2), 145-165.

Cecchetti, S., \& Kharroubi, E. (2012). Reassessing the impact of finance on growth (No. 381). Bank for International Settlements.

Cha, H. S., Pingry, D. E., \& Thatcher, M. E. (2009). What determines IT spending priorities? Communications of the ACM, 52(8), 105-110.

Chen, M.-C., Cheng, S.-J., \& Hwang, Y. (2005). An empirical investigation of the relationship between intellectual capital and firms' market value and financial performance. Journal of Intellectual Capital, 6(2), 159-176.

Coad, A., \& Rao, R. (2010). Firm growth and R\&D expenditure. Economics of Innovation and New Technology, 19(2), 127-145.

Dave, P., Wadhwa, V., Aggarwal, S., \& Seetharaman, A. (2013). The impact of research and development on the financial sustainability of information technology (IT) companies listed on the S\&P 500 index. Journal of Sustainable Development, 6(11), 122.

Denicolai, S., Zucchella, A., \& Strange, R. (2014). Knowledge assets and firm international performance. International Business Review, 23(1), 55-62.

Eberhart, A. C., Maxwell, W. F., \& Siddique, A. R. (2004). An examination of long-term abnormal stock returns and operating performance following R\&D increases. The Journal of Finance, 59(2), $623-$ 650.

García-García, J., \& de Magdaleno, M. A. (2010). Fair value on Open Source business. XIV Encuentro AECA, Coimbra (Portugal).

Garger, J. (2010). Equity and market value: How much is a company worth to an investor. In.

Grant, R. M. (1996). Toward a knowledge-based theory of the firm. Strategic Management Journal, 17(S2), 109-122.

Hall, B. H., \& Lerner, J. (2010). The financing of R\&D and innovation. In Handbook of the Economics of Innovation (Vol. 1, pp. 609-639): Elsevier. 
Helfat, C. E., \& Peteraf, M. A. (2003). The dynamic resource-based view: Capability lifecycles. Strategic Management Journal, 24(10), 997-1010.

Hsieh, P.-H., Mishra, C. S., \& Gobeli, D. H. (2003). The return on R\&D versus capital expenditures in pharmaceutical and chemical industries. IEEE Transactions on Engineering Management, 50(2), 141-150.

Hsu, I.-C., \& Sabherwal, R. (2011). From intellectual capital to firm performance: the mediating role of knowledge management capabilities. IEEE Transactions on Engineering Management, 58(4), 626-642.

Jirásek, M. (2017). The Relationship Between R\&D Spending Instability and a Firm 's Performance.

Jirásek, M. (2018). Financial Performance Feedback and R\&D: A Comparison of Different Models. Quality Innovation Prosperity, 22(1), 01-13.

Kalleberg, A. L., Marsden, P. V., Reynolds, J., \& Knoke, D. (2006). Beyond profit? Sectoral differences in high-performance work practices. Work and Occupations, 33(3), 271-302.

Kianto, A., Andreeva, T., \& Pavlov, Y. (2013). The impact of intellectual capital management on company competitiveness and financial performance. Knowledge Management Research \& Practice, 11(2), 112-122.

Kogut, B., \& Zander, U. (1992). Knowledge of the firm, combinative capabilities, and the replication of technology. Organization Science, 3(3), 383-397.

Kothari, S., Laguerre, T. E., \& Leone, A. J. (2002). Capitalization versus expensing: Evidence on the uncertainty of future earnings from capital expenditures versus R\&D outlays. Review of accounting Studies, 7(4), 355-382.

Lantz, J.-S., \& Sahut, J.-M. (2005). R\&D investment and the financial performance of technological firms. International Journal of Business, 10(3), 251.

Lin, C-H., Yang, H-L., \& Liou, D.-Y. (2009). The impact of corporate social responsibility on financial performance: Evidence from business in Taiwan. Technology in Society, 31(1), 56-63.

Lome, O., Heggeseth, A. G., \& Moen, Ø. (2016). The effect of R\&D on performance: Do R\&D-intensive firms handle a financial crisis better? The Journal of High Technology Management Research, 27(1), 65-77.

Martin, M. (2015). Effectiveness of Business Innovation and R\&D in Emerging Economies: The Evidence from Panel Data Analysis. Journal of Economics Business and Management, 3(4), 440446.

Menor, L. J., Kristal, M. M., \& Rosenzweig, E. D. (2007). Examining the influence of operational intellectual capital on capabilities and performance. Manufacturing \& Service Operations Management, 9(4), 559-578.

Pandit, S., Wasley, C. E., \& Zach, T. (2011). The effect of research and development (R\&D) inputs and outputs on the relation between the uncertainty of future operating performance and R\&D expenditures. Journal of Accounting, Auditing \& Finance, 26(1), 121-144.

Peterson, R. A., \& Jeong, J. (2010). Exploring the impact of advertising and R\&D expenditures on corporate brand value and firm-level financial performance. Journal of the Academy of Marketing Science, 38(6), 677-690.

Rafiq, S., Salim, R., \& Smyth, R. (2016). The moderating role of firm age in the relationship between R\&D expenditure and financial performance: Evidence from Chinese and US mining firms. Economic Modelling, 56, 122-132.

Schimke, A., \& Brenner, T. (2014). The role of R\&D investments in highly R\&D-based firms. Studies in Economics and Finance, 31(1), 3-45.

Sehrawat, M., \& Giri, A. (2017). A Sectoral Analysis of the Role of Stock Market Development on Economic Growth: Empirical Evidence from Indian Economy. Global Business Review, 18(4), 911-923.

Sher, P. J., \& Yang, P. Y. (2005). The effects of innovative capabilities and R\&D clustering on firm performance: the evidence of Taiwan's semiconductor industry. Technovation, 25(1), 33-43. 
Shin, N., Kraemer, K. L., \& Dedrick, J. (2009). R\&D, value chain location and firm performance in the global electronics industry. Industry and Innovation, 16(3), 315-330.

Siegel, J. J., \& Schwartz, J. D. (2006). Long-term returns on the original S\&P 500 companies. Financial Analysts Journal, 62(1), 18-31.

Teirlinck, P. (2017). Configurations of strategic R\&D decisions and financial performance in small-sized and medium-sized firms. Journal of Business Research, 74, 55-65.

Tubbs, M. (2007). The relationship between R\&D and company performance. Research-Technology Management, 50(6), 23-30.

VanderPal, G. A. (2015). Impact of R\&D Expenses and Corporate Financial Performance. Journal of Accounting and Finance, 15(7), 135.

Wang, C.-H. (2011). Clarifying the Effects of R\&D on Performance: evidence from the high technology industries. Asia Pacific Management Review, 16(1), 51-64. 